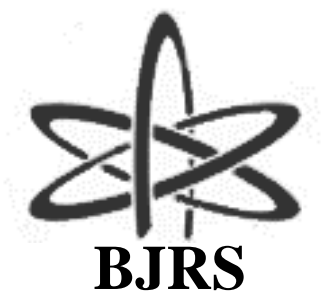
BRAZILIAN JOURNAL $\mathrm{OF}$ RADIATION SCIENCES 07-02A (2019) 01-10

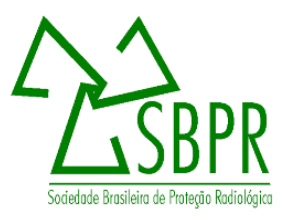

\title{
Radioactive Background of Granito Madeira, North
}

\author{
Amazonas, Brazil \\ Moura V. V., Santos T. O., Pereira C. \\ 662, CEP 31270-901 Belo Horizonte, $M G$ \\ vandermoura@gmail.com
}

Departamento de Engenharia Nuclear. Universidade Federal de Minas Gerais. Av. Presidente Antônio Carlos,

\begin{abstract}
Radionuclides of natural origin are present in rocks and soils but have no homogeneous distribution in the soil of the Earth. Volcanic rocks have a higher concentration of uranium and thorium. Thus, sites with this type of origin present as radiological abnormalities. An example is the Planalto de Poços de Caldas in Minas Gerais. Another example is the Granito Madeira - a rock formation located in the Amazonas State, $350 \mathrm{~km}$ north of Manaus. This work presents the results of the natural radiation monitoring of Granito Madeira. 30,000 dose rates were collected with a sodium iodide scintillator transported on tracks within the Floresta Amazônica. These data were treated and georeferenced. As a result, an annual dose relative to gamma radiation of 6.0 mSv.year ${ }^{-1}$ was obtained. This information was represented in a frequency histogram and in a map of Granito Madeira.
\end{abstract}

Keywords: radioactive background, dose rate, georeferencing.

ISSN: 2319-0612

Accept Submission: 2019-01-03 


\section{INTRODUCTION}

The human being is continuously exposed to ionizing radiation by sources used in medicine, industry and, mainly, by natural sources. The latter is responsible for the existence of natural background radiation [1].

Natural sources of radiation are due to cosmic rays and natural radionuclides. These can be classified into two main types. The first is the cosmogenic radionuclides, arising from the interactions between high energy particles from space with gases in the atmosphere. As an example, carbon-14 is cited [2].

The second type is the primordial radionuclides such as the decay series of U-238 (uranium238), U-235 (uranium-235) and Th-232 (thorium-232) that originate from the planet's own formation Earth. These radionuclides are present in sands, soils, and rocks. It is found all over the surface of the Earth. But this distribution is not homogeneous. It depends on the type of rock, with magmatic ones such as granite having higher concentrations of radionuclides from the uranium and thorium series and, consequently, areas of natural radioactivity higher than the world average [3]. In Brazil, examples are the Planalto de Poços de Caldas in Minas Gerais [4] and the Escudo das Guianas in Pará and Amazonas [5].

There are several published works about the radioactive background of the Planalto de Poços de Caldas. It should be noted that SACHETT, 2002, using a scintillation detector, monitored dose rates relative to gamma radiation in four cities in the region. He obtained annual doses ran ging from $0.61 \mathrm{mSv}$.year ${ }^{-1}$ to $0.89 \mathrm{mSv}$.year ${ }^{-1}$ [4]. These results are higher than the world average of 0.48 mSv.year ${ }^{-1}$ [6]. On the other hand, there are few studies on the Escudo das Guianas region. Thus, in this article, the Granito Madeira was selected - a rock formation located on the Escudo das Guianas that is located $350 \mathrm{~km}$ north of Manaus, capital of Amazonas State, according to Figure 1 [7].

The Granito Madeira presents mineralization of several elements with emphasis on tin, niobium, tantalum, zirconium, rare earths, aluminum, uranium and thorium [8]. Thus, it is an area of economic potential and currently presents about $5 \%$ of its area in the process of mineral exploration. The other $95 \%$ is covered by the Floresta Amazônica. 
Figure 1: Location of Granito Madeira.

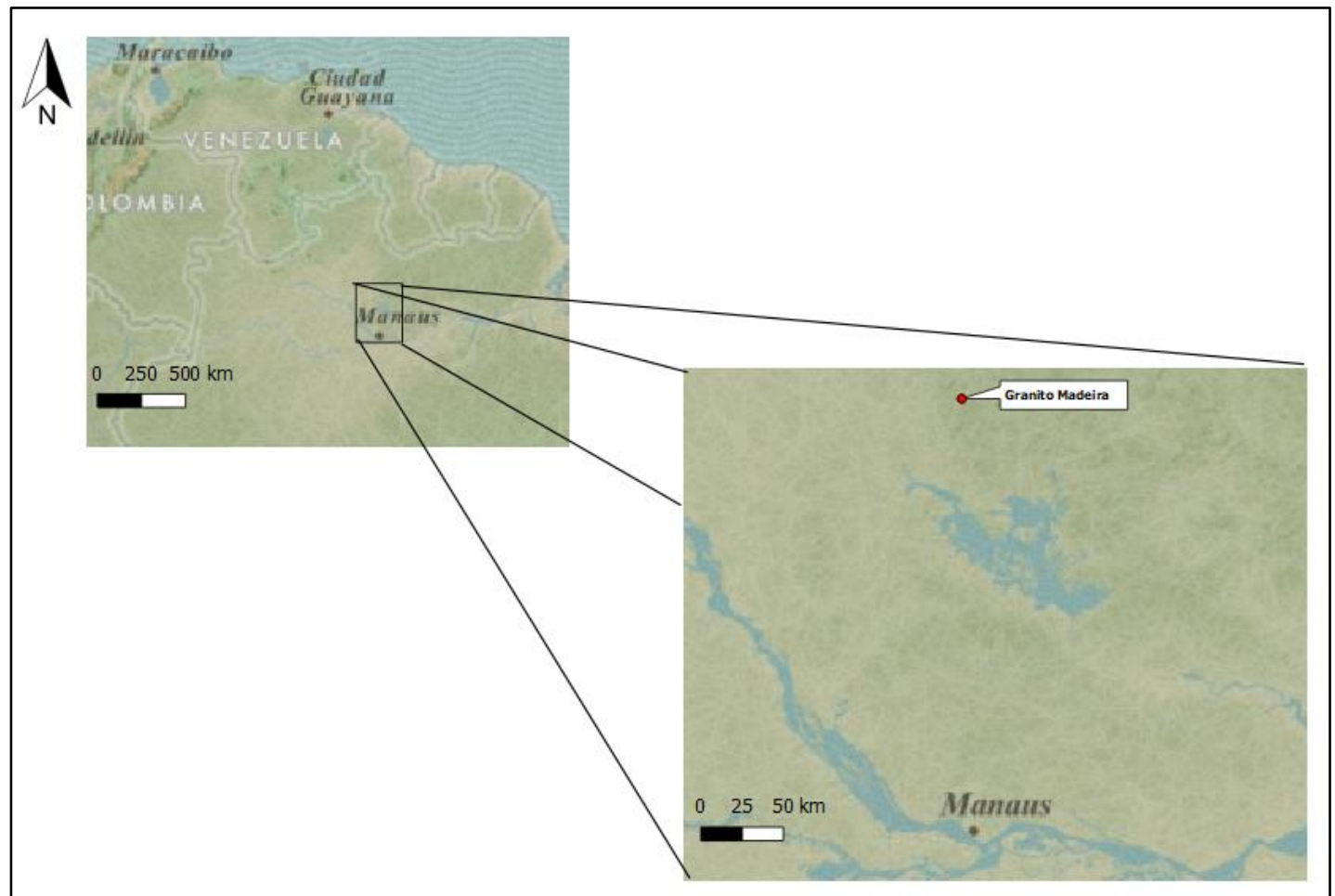

The objective of this work is to map and evaluate the background radiation to estimate the annual doses relative to gamma radiation in the Granito Madeira.

\section{MATERIALS AND METHODS}

\subsection{Equipment}

The equipment used in this study was a scintillator detector - Atomtex AT6101C Spectrometer System. It is a sodium iodide detector designed to monitor the dose rate and some associated electronics that transfers the data to monitored computers. The selection of the equipment was carried out taking into account the energy range since it is indicated for use of monitoring of gamma radiation from $50 \mathrm{keV}$ to $3 \mathrm{Mev}$ [9] - emission range of most radionuclides from a family of natural uranium and family of natural thorium. Another factor in the selection is the fact that it is reading, 
in dose rate, is in the range of $0.01 \mathrm{uSv} \cdot \mathrm{h}^{-1}$ to $150 \mathrm{uSv} \cdot \mathrm{h}^{-1}$ which is within the expected range for natural background radiation [6].

The equipment is portable and can be transported inside a backpack (A) - see Figure 2. The scintillator (B) detects gamma radiation. This information is transmitted (C) via Bluetooth to the manual receiver (D) which has a Global Positioning System (GPS). Thus, it associates this data with the geographic coordinates of the monitored point by creating text files (txt) and commaseparated files (CSV) that can be used in georeferencing and data processing software [9].

Figure 2: AT6101C Spectrometer System.

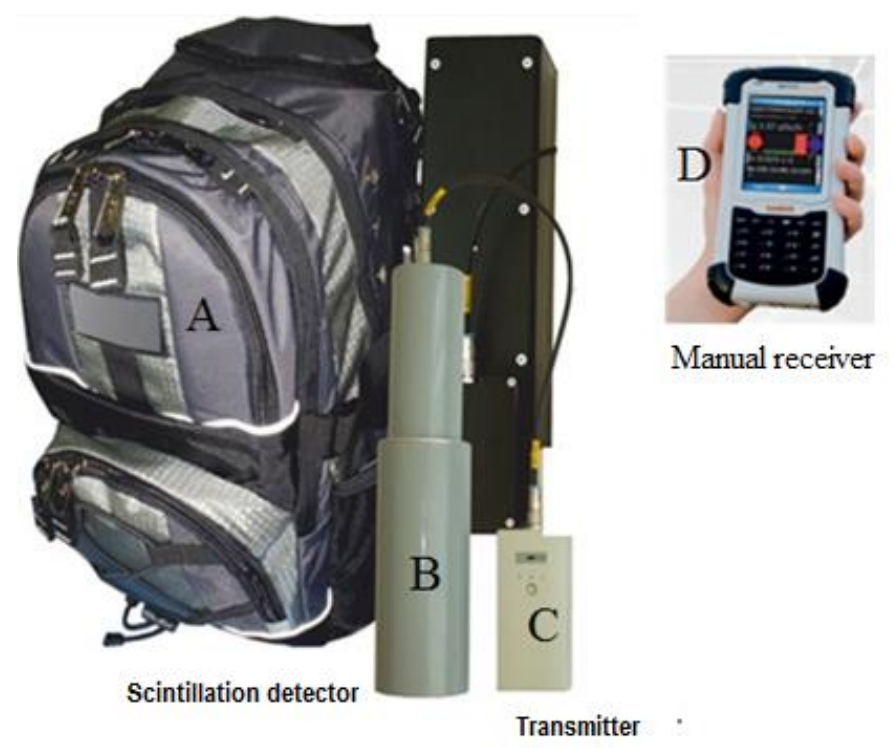

\subsection{Software}

The data obtained in the monitoring were treated by the software listed in Table 1.

Table 1: Software used.

\begin{tabular}{lll}
\hline \multicolumn{1}{c}{ Software } & Manufacturer & \multicolumn{1}{c}{ Use } \\
\hline Atas Scanner & Atomtex & Controlling the AT6101C System. \\
Garm & Atomtex & Generate georeferenced files. \\
Quantum Gis & Open Source & Create maps and georeferenced. \\
\hline
\end{tabular}


The ATAS scanner is the software responsible for managing the AT6101C System, communication between scintillator and hand receiver, the association of dose rates with GPS data and the visualization of information in real time. It is installed on the handset [10].

The GARM software (Geolocation Application for Radiation Monitoring) is installed on the computer and it is used for visualization of the monitored data, generation of files with georeferenced data, text files (.txt) and comma-separated files (.CSV) for use in other software [11].

Quantum Gis or QGis is the software for analysis, storage, manipulation, visualization and management of information in databases. Thus, it can integrate parameters of interest, such as the data of this work, with a geographic information system (GIS) allowing the visualization in sketches or maps in different projections from the files generated by GARM. It can also be used to generate iso-value maps by the inverse interpolation technique of the square of the distance [12].

\subsection{Methods}

The Granito Madeira is a rock formation located in the Floresta Amazônica with a marked topography and few accesses. Thus, data collection was performed by transporting the AT6101C Spectrometer System through $37 \mathrm{~km}$ of pre-existing trails through the areas indicated in Figure 3.

When plugging, the AT6101 System receives the data relating to the geographic coordinates of the satellites. The ATAS software collects and associates this information at the dose rates every 10 seconds [10].

The data obtained by the monitoring were treated by the GARM software generating files with the information of the dose rates and geographic coordinates. Subsequently, the product of the dose rates was performed by the number of hours of a standard year ( 8760 hours) to obtain the annual doses relative to gamma radiation.

The annual doses and the corresponding geographic coordinates were geoprocessed by the QGIS software for the generation of iso-dose curves by the inverse of the square of the distance. This information was made available on a map [13]. 
Figure 3: Monitored areas.

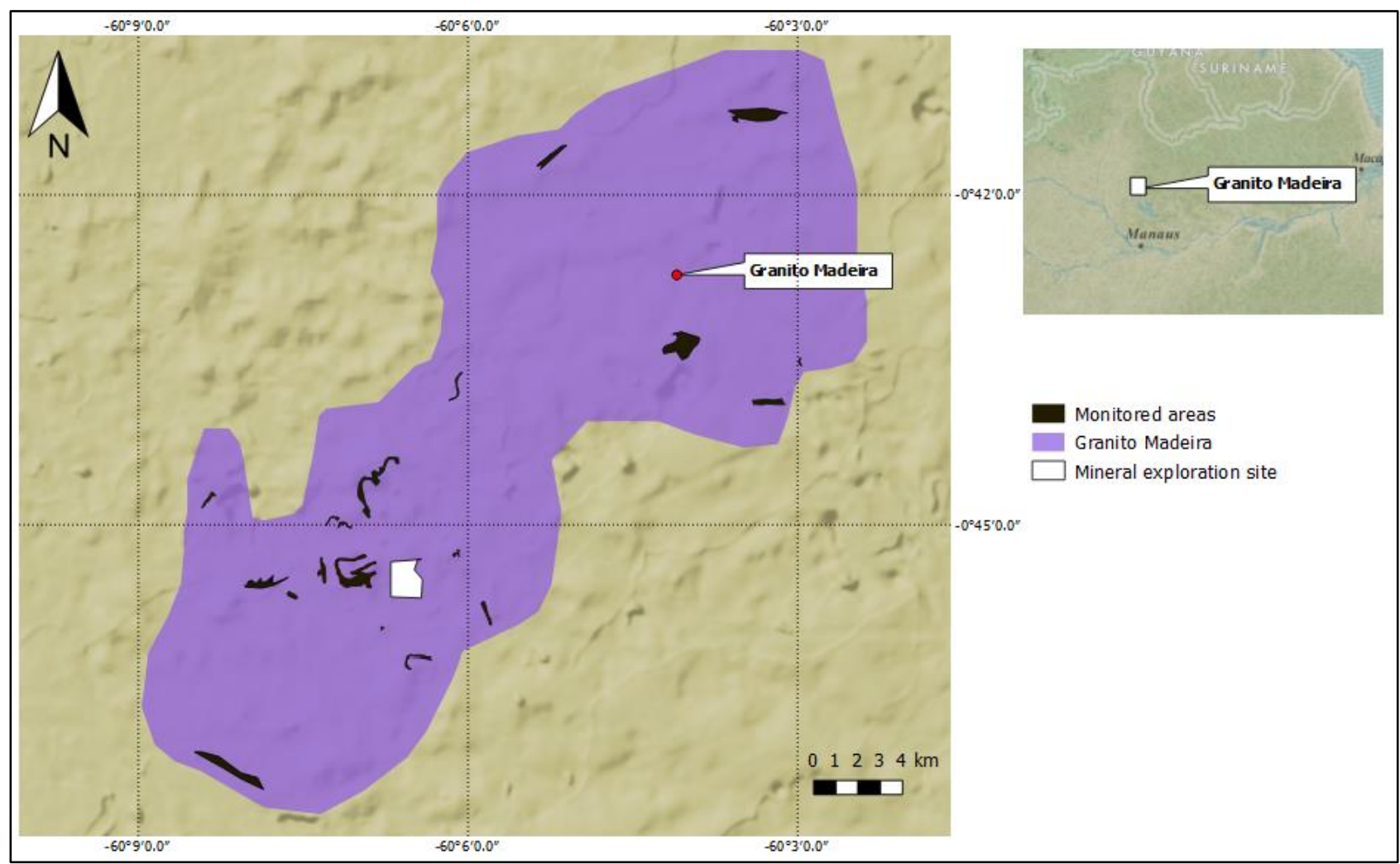

\section{RESULTS AND DISCUSSIONS}

Figure 4 shows the frequency histogram for the 30,000 dose rates collected on Granito Madeira. The average dose rate obtained was $(0.7 \pm 0.4) \mathrm{uSv} \cdot \mathrm{h}^{-1}$. It is observed that around $70 \%$ of the rates are in classes $0.47 \mathrm{uSv} \cdot \mathrm{h}^{-1}$ and $0.77 \mathrm{uSv} \cdot \mathrm{h}^{-1}$.

Figure 5 shows the spatial distribution of annual doses relative to gamma radiation in Granito Madeira. The highest values of background radioactivity were found around the sites where the mineral exploration occurs. This is probably due to:

i) the association between the radionuclides of the uranium and thorium decay chains and the other granite matrix materials. As in mineral exploration sites, the concentration of the mineral of interest is higher, the concentration of radionuclides is also higher. 
ii) the decanting of the dust present in the atmosphere and its precipitation together with the rain.

Figure 4: Frequency histogram of the monitored dose rates of Granito Madeira.

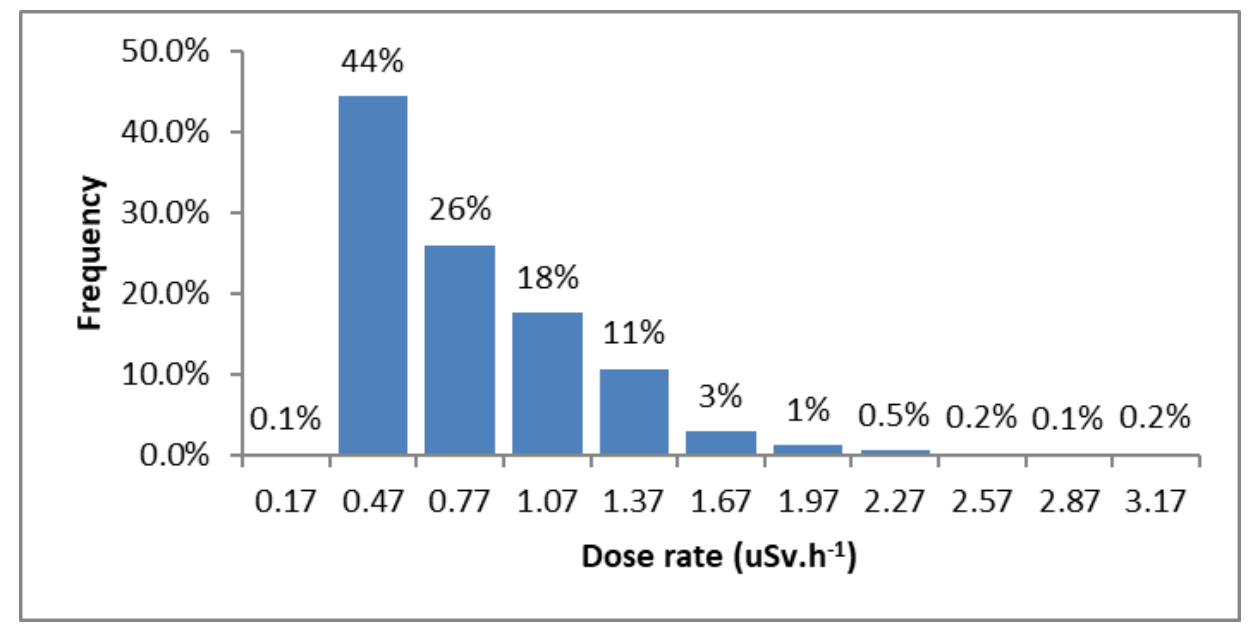

Figure 5: Spatial distribution of annual doses relative to gamma radiation in Granito Madeira.

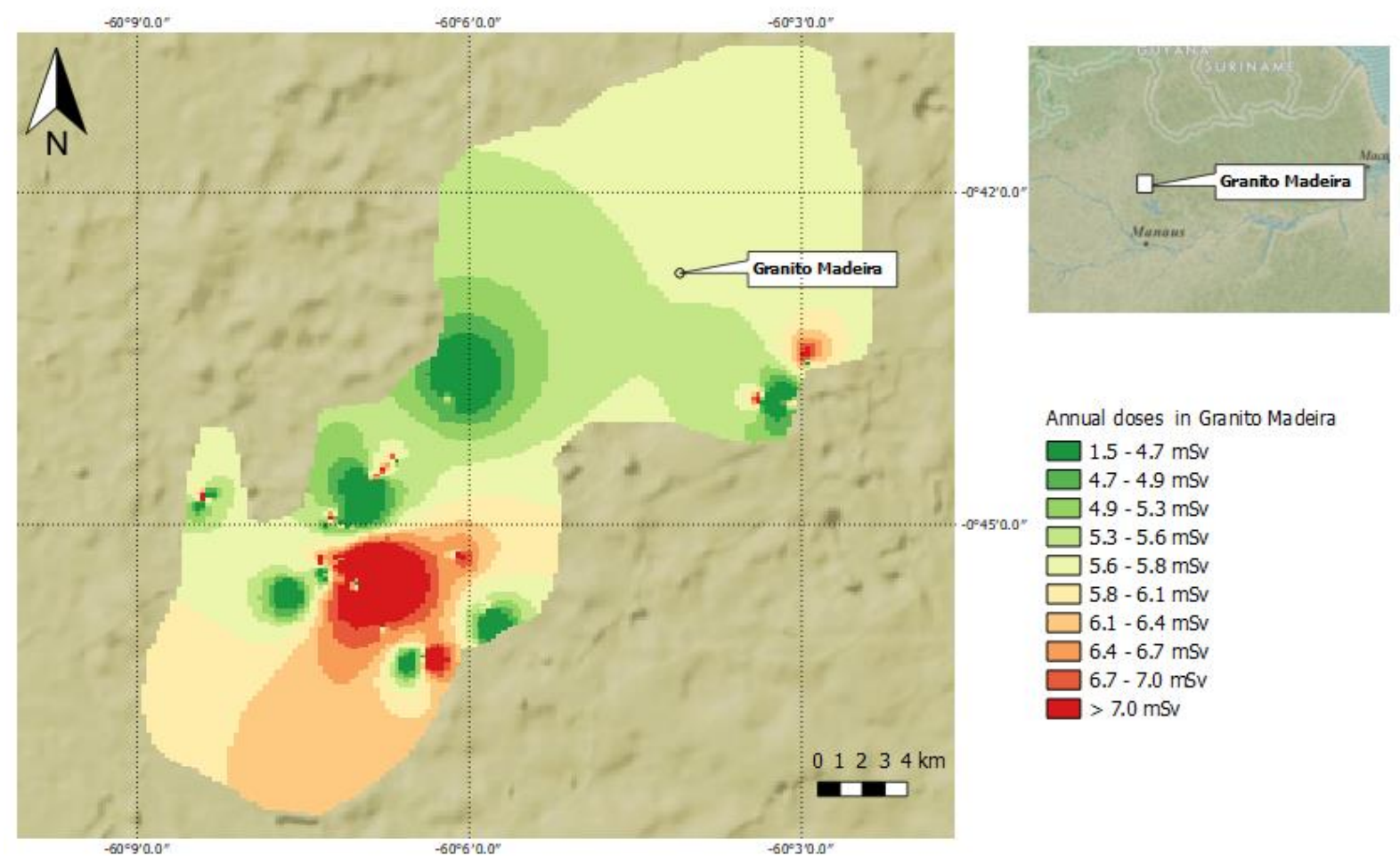


Table 2 presents the comparison between the annual dose in Granito Madeira, in the Planalto de Poços de Caldas [4] and the world average [6]. It is observed that the results of this study are much higher.

Table 2: Comparison between the annual dose.

\begin{tabular}{lcc}
\hline \multicolumn{1}{c}{ Local } & $\begin{array}{c}\text { Average } \\
\left(\text { mSv.year }^{-1}\right)\end{array}$ & $\begin{array}{c}\text { Range } \\
\left(\text { mSv.year }^{-1}\right)\end{array}$ \\
\hline World & 0.48 & $0.3-1$ \\
Planalto de Poços de Caldas-MG & - & $0.61-0.89$ \\
Granito Madeira-AM & $6.0^{*}$ & $1.5-27.8^{*}$ \\
\hline *in 8760 h. year $^{-1}$ & &
\end{tabular}

\section{CONCLUSION}

The monitoring of the dose rates of Granito Madeira showed that the site presents background radiation higher than the world average and that the Planalto de Poços de Caldas. This information should be considered in future explorations in that it will help in the design of radiation protection programs and to establish dose limits for decommissioning of the area.

\section{REFERENCES}

[1] MARTIN, J. E. Physics for Radiation Protection, Weinheim: WILEY-VCH Verlag GmbH \& Co, 2006.

[2] ARAMBURU, X. O.; BISBAU, J. J. Radiaciones Ionizantes - Utilización y Riesgos, Barcelona: Ediciones UPC, 1994.

[3] KARAM, P. A. Naturally-Occurring Radioactive Materials (NORM), Nevada: Nevada Technical Associates. 
[4] SACHETT, I. A. Caracterização da Radiação Gama Ambiental em Áreas Urbanas utilizando uma Unidade Móvel de Rastreamento, Tese (Doutorado). Rio de Janeiro: UFRJ, 2002.

[5] COSTA, C. F. M. Evolução Geológica da Região de Pitinga (Amazonas) e suas Implicações na Gênese da Mineralização de Sn-Nb-Ta-F (Y-ETR-Li) Associada ao Granito Madeira, Tese (Doutorado em Geociências). Porto Alegre: UFGRS, 2010.

[6] UNSCEAR - United Nations Scientific Committee on the Effects of Atomic Radiation. UNSCEAR 2008 - Sources and Effects of Ionizing Radiation, New York: UNITED NATIONS, 2010. 683p.

[7] PRADO, M. O Granito Europa e o Grupo Iricoumé na Parte Leste do Distrito Mineiro de Pitinga (Amazonas), Dissertação (Mestrado em Geociências). Porto Alegre: UFRGS, 2006.

[8] COSTI, H. T.; BORGES; R. M. K.; DALL'AGNOLL, R. Depósitos de Estanho da Mina Pitinga, Estado Amazonas. In: Caracterização de Depósitos Minerais em Distritos Mineiros da Amazônia, pp. 391-476, 2005.

[9] ATOMTEX. Spectrometer AT6101C - Spectral Radiaction Scanner - User Manual, Minsk: ATOMTEX, 2010.

[10] ATOMTEX. Atas Scanner Mobile - Software User's Manual, Minsk: ATOMTEX, 2010.

[11] ATOMTEX. GARM Program - Software User's Manual, Minsk: ATOMTEX, 2010.

[12] PROJECT QGIS. QGIS PROJECT. QGIS User Guide Release 1.8, 2014. Available: <http://docs.qgis.org/1.8/pdf/QGIS-1.8-UserGuide-en.pdf> Last accessed 10 Sept. 2017. 
[13] SILVA, R. M. Introdução ao Geoprocessamento: conceitos, técnicas e aplicações, Novo Hamburgo: Feevale, 2007. 